\title{
Macronutrients and Human Health for the 21st Century
}

\author{
Bernard J. Venn \\ Department of Human Nutrition, University of Otago, Dunedin 9054, New Zealand; bernard.venn@otago.ac.nz \\ Received: 30 July 2020; Accepted: 4 August 2020; Published: 7 August 2020 \\ check for \\ updates
}

\begin{abstract}
Fat, protein and carbohydrate are essential macronutrients. Various organisations have made recommendations as to the energy contribution that each of these components makes to our overall diet. The extent of food refining and the ability of food systems to support future populations may also impact on how macronutrients contribute to our diet. In this Special Issue, we are calling for manuscripts from all disciplines to provide a broad-ranging discussion on macronutrients and health from personal, public and planetary perspectives.
\end{abstract}

Keywords: macronutrient; fat; protein; carbohydrate; acceptable macronutrient distribution range; starch; sustainability

The macronutrients, fat, protein and carbohydrate provide energy and essential components to sustain life. Fat is composed of glycerol and fatty acids; protein is an agglomeration of amino acids; and carbohydrate is simple sugars occurring either as monosaccharides or chains of connected monosaccharides (e.g., starch) whose bonds are either hydrolysed in the human small intestine to monosaccharides or are resistant to hydrolysis (dietary fibre). To maintain longevity and health, a combination of these macronutrients is required in our diet. It is elusive as to whether there is a combination of macronutrients that provides optimal health. When expressed as a percentage of energy to the diet, human populations have historically survived on diets with greatly differing proportions of these macronutrients. For example, the animal-based diet of an Alaskan Inuit group was found to comprise $33 \%$ protein, $41 \%$ fat and $26 \%$ carbohydrate [1]. This dietary pattern was consistent with low dental caries and it was proposed that it was cardioprotective, although this was subsequently found to be an erroneous assumption [2]. In contrast, the diet of Irish farm workers, principally potato and skim milk, provided $12 \%$ protein, $1 \%$ fat, and $87 \%$ carbohydrate; this diet was temporally associated with an exceptionally low rate of death from diabetes mellitus [3]. High-carbohydrate diets have also been used for the treatment of diabetes and vascular disorders, as described by Kempner and colleagues using a rice-based diet [4]. The carbohydrate in rice and potato is predominantly starch, with starch-based diets providing $12 \%$ protein, $7 \%$ fat and $81 \%$ carbohydrate used to good effect in improving markers of health over 7 days [5]. Using a similar low-fat (7-15\%) dietary approach in which starchy foods were encouraged, together with whole grains, legumes, vegetables and fruits, overweight or obese patients with comorbidities lost weight and improved metabolic risk factors over 12 months [6]. From an evolutionary viewpoint, humans are well adapted to digesting starch [7]. However, despite the apparent health benefits of following high-starch diets based on root vegetables, legumes and unrefined grains, the proportions of macronutrients provided by such diets would generally be regarded as incongruous with an acceptable macronutrient distribution range (AMDR). Some examples of health authorities' guidance are given in Table 1. 
Table 1. Dietary recommendations of \% energy contribution to diet based on the prevention of chronic disease.

\begin{tabular}{|c|c|c|c|}
\hline Source & Protein & Fat & Carbohydrate \\
\hline New Zealand and Australia [8] & $15-25$ & 20-35 & $45-65$ \\
\hline North America [9] & $\begin{array}{l}10-30 \text { youth } \\
10-35 \text { adults }\end{array}$ & $\begin{array}{l}25-35 \text { youth } \\
20-35 \text { adults }\end{array}$ & $45-65$ \\
\hline United Kingdom [10] & - & $<35$ & 50 \\
\hline World Health Organization [11] & $10-15$ & $15-30$ & $55-75$ \\
\hline
\end{tabular}

The range for each macronutrient is relatively wide, allowing for dietary diversity. The higher contribution of carbohydrate given by the World Health Organization compared with the listed countries may be due to observations of good health associated with traditional diets containing unrefined sources of carbohydrate-containing foods. In developed countries, there is concern that refined carbohydrates are contributing to the aetiology of non-communicable disease, and perhaps the inclusion of refined foods modifies the AMDR. A carbohydrate content of $50-55 \%$ has been associated with a low risk of mortality in a modern Western setting [12]. Further insight may be gained following an intervention study in which people will eat diets differing in macronutrient composition for 6 months [13]. However, whether there is a single optimal lifelong macronutrient distribution is also questionable. Modelling dietary intakes for protection against Alzheimer's disease is suggestive that protein intake should be around $6 \%$ in middle-aged individuals, increasing to $17 \%$ thereafter [14].

Consistently around the world, traditional diets of legumes, other vegetables, and coarse grains are being replaced by diets typically higher in animal fat and plant-derived oils, added sugars, animal-source foods, and refined carbohydrates [15]. For example, in Vietnam over the period from 1985 to 2010, the proportion of energy from carbohydrate declined from 83 to $67 \%$, whilst that of fat increased from 6 to 18\% [16]. This change in dietary composition was associated with an increase in the height of the population, attributed to a higher energy intake but also with an increase in the prevalence of type 2 diabetes [17]. The association of diet with type 2 diabetes is complex and is often coupled with urbanisation resulting in lower levels of physical activity [18]. There is no doubt that diet and activity interact with insulin resistance, an obligate component of type 2 diabetes, found to be related to intramyocellular saturated fatty acid, an effect that is ameliorated with exercise [19]. Thus, from ecological observation to sophisticated laboratory techniques, proportional macronutrient intake is inextricably linked to health. The foods that are used to generate the macronutrient composition are also crucial to the healthfulness of our diet, and, from a planetary resource perspective, plant protein is more sustainable than animal protein [20].

Funding: This research received no external funding.

Conflicts of Interest: The author declares no conflict of interest.

\section{References}

1. Bang, G.; Kristoffersen, T. Dental caries and diet in an Alaskan Eskimo population. Scand. J. Dent. Res. 1972, 80, 440-444. [CrossRef] [PubMed]

2. Fodor, J.G.; Helis, E.; Yazdekhasti, N.; Vohnout, B. "Fishing" for the origins of the "Eskimos and heart disease" story: Facts or wishful thinking? Can. J. Cardiol. 2014, 30, 864-868. [CrossRef] [PubMed]

3. Crawford, E.M. Death rates from diabetes mellitus in Ireland 1833-1983: A historical commentary. Ulster Med. J. 1987, 56, 109-115. [PubMed]

4. Kempner, W.; Peschel, R.L.; Schlayer, C. Effect of rice diet on diabetes mellitus associated with vascular disease. Postgrad. Med. 1958, 24, 359-371. [CrossRef] [PubMed]

5. McDougall, J.; Thomas, L.E.; McDougall, C.; Moloney, G.; Saul, B.; Finnell, J.S.; Richardson, K.; Petersen, K.M. Effects of 7 days on an ad libitum low-fat vegan diet: The McDougall Program cohort. Nutr. J. 2014, 13, 99. [CrossRef] [PubMed] 
6. Wright, N.; Wilson, L.; Smith, M.; Duncan, B.; McHugh, P. The BROAD study: A randomised controlled trial using a whole food plant-based diet in the community for obesity, ischaemic heart disease or diabetes. Nutr. Diabetes 2017, 7, e256. [CrossRef] [PubMed]

7. Pajic, P.; Pavlidis, P.; Dean, K.; Neznanova, L.; Romano, R.A.; Garneau, D.; Daugherity, E.; Globig, A.; Ruhl, S.; Gokcumen, O. Independent amylase gene copy number bursts correlate with dietary preferences in mammals. eLife 2019, 8, e44628. [CrossRef] [PubMed]

8. Australian Government and New Zealand Ministry of Health. Nutrient Reference Values for Australia and New Zealand; Commonwealth of Australia: Canberra, Australia, 2006.

9. Institute of Medicine. Dietary Reference Intakes for Energy, Carbohydrate. Fiber, Fat, Fatty Acids, Cholesterol, Protein, and Amino Acids (2002/2005); The National Academies Press: Washington, DC, USA, 2002.

10. United Kingdom Department of Health. Dietary Reference Values for Food Energy and Nutrients for the United Kingdom. In Report on Health and Social Subjects; The Stationary Office: London, UK, 1991.

11. World Health Organization. Diet, Nutrition and the Prevention of Chronic Diseases; WHO Technical Report Series 916; WHO/FAO Expert Consultation: Geneva, Switzerland, 2003.

12. Seidelmann, S.B.; Claggett, B.; Cheng, S.; Henglin, M.; Shah, A.; Steffen, L.M.; Folsom, A.R.; Rimm, E.B.; Willett, W.C.; Solomon, S.D. Dietary carbohydrate intake and mortality: A prospective cohort study and meta-analysis. Lancet Public Health 2018, 3, e419-e428. [CrossRef]

13. Wan, Y.; Wang, F.; Yuan, J.; Li, D. Optimal dietary macronutrient distribution in China (ODMDC): A randomised controlled-feeding trial protocol. Asia Pac. J. Clin. Nutr. 2017, 26, 972-980. [PubMed]

14. Studnicki, M.; Debski, K.J.; Stepkowski, D. Proportions of macronutrients, including specific dietary fats, in prospective anti-Alzheimer's diet. Sci. Rep. 2019, 9, 20143. [CrossRef] [PubMed]

15. Popkin, B.M. Nutrition Transition and the Global Diabetes Epidemic. Curr. Diabetes. Rep. 2015, $15,64$. [CrossRef] [PubMed]

16. National Institute of Nutrition Vietnam. United Nations Children Fund. In Summary Report; General Nutrition Survey: 2009-2010; National Institute of Nutrition Vietnam: Hanoi, Vietnam, 2012.

17. Duc Son, L.N.; Kusama, K.; Hung, N.T.; Loan, T.T.; Chuyen, N.V.; Kunii, D.; Sakai, T.; Yamamoto, S. Prevalence and risk factors for diabetes in Ho Chi Minh City, Vietnam. Diabet. Med. 2004, 21, 371-376. [CrossRef] [PubMed]

18. Gassasse, Z.; Smith, D.; Finer, S.; Gallo, V. Association between urbanisation and type 2 diabetes: An ecological study. BMJ Glob. Health 2017, 2, e000473. [CrossRef] [PubMed]

19. Savage, D.B.; Watson, L.; Carr, K.; Adams, C.; Brage, S.; Chatterjee, K.K.; Hodson, L.; Boesch, C.; Kemp, G.J.; Sleigh, A. Accumulation of saturated intramyocellular lipid is associated with insulin resistance. J. Lipid Res. 2019, 60, 1323-1332. [CrossRef] [PubMed]

20. EAT. Summary Report of the EAT Lancet Commission, Internet. Available online: https://eatforum.org/eatlancet-commission/eat-lancet-commission-summary-report/ (accessed on 29 July 2020).

(C) 2020 by the author. Licensee MDPI, Basel, Switzerland. This article is an open access article distributed under the terms and conditions of the Creative Commons Attribution (CC BY) license (http://creativecommons.org/licenses/by/4.0/). 